\title{
Development Trends of Entrepreneurial Activity in the Republic of Tatarstan
}

\author{
Shafigullina A.V. ${ }^{a}$ \\ Akhmetshin R.M. ${ }^{\mathrm{b}}$
}

a b Kazan Federal University, Institute of Management, Economics and Finance, Kazan, 420008, Russia

\section{Doi:10.5901/mjss.2015.v6n1s3p495}

\section{Abstract}

The article discusses the current state of small business. Authors identify small businesses' development trends within the framework of endogenous approach. The article discloses the key challenges and problems of current status of the business sector based on asymmetric structure.

Keywords: small and medium entrepreneurship, small business, infrastructure, government support.

\section{Introduction}

The transformation of the Russian economy's social and economic priorities has determined an interchange between the business activity's paradigms. Small entities have become a basic for economic development through establishing optimal structure for entrepreneurial activity's objects.

This, in turn, will lead to the revision of the evaluation tools for the entrepreneurial activity's effectiveness and, as a consequence, it will impact of the development and implementation of flexible strategy and management tactics, the development of a strong economic motivation and personal responsibility for the production results.

\section{Theory}

Analysis of the government support effectiveness in business development process, on our opinion, should be reviewed in the framework of endogenous approach. Because this approach is based on changes appeared as a result of establishment of government economic policy, through designation of the values and mechanisms of relationship between system's subjects, which is affected by this policy.

Effectiveness of the applied tools, which are aimed to support entrepreneurial activity, depends on the "parallelism" of economic policy reforms and internal (institutional) changes in business. Besides, the fact, that government economic regulating policy must be consistent with the economic expediency of business support programs, should be borne in mind.

The importance of small business development involves a comprehensive solution of the following problems:

- Coordination between the activities carried out by all organizations involved in a process of governmental support for small businesses at different governmental levels;

- Stage improvement of infrastructure for small business;

- Selective approach implementation in governmental policy, directed to support small business and complying with operational scope.

Small entrepreneurship is contributing in optimization of economic structure, and mostly to the regional one, due to its flexibility and ability to occupy the smallest market niches. It facilitates flexible reengineering of the production process, growth of employment, building a business culture and active innovation filed; initiates the capital accumulation and defuses social conflicts.

It should be noted that not only registered companies' number but also other indices describing the real financial and economic activity of small businesses - such as share of GDP, the average number of employees, turnover, fixed capital investment are reflecting entrepreneurial activity.

Industrial composition remains almost invariable over a range of years. Significant asymmetry persisting over the regional development is being observed both in Russian Federation's and Tatarstan's entrepreneurship structure, as we assume. 


\section{Results}

In 2010, in the GRP's production structure small enterprises shared $21.6 \%$ in mining sector, manufacturing sector contributed in amount of $17 \%$ into the small business turnover, trade presented $14 \%$, construction - 9\%, transport and communication, and agriculture $-16.8 \%$ and $21.6 \%$ were other activities.

It can be seen from Fig.1 the GRP's production structure of 2013 has not changes much, which means that despite the measures taken by the government, Tatarstan entrepreneurship structures has not overcome the asymmetric development.

Enhancement of some entrepreneurship positions can be observed. However, scientists think that this strengthening is a result of attracting investment into mining and agricultural sectors, as well as holding international youth sports events le to stimulation of SME development in the fields of constructions and trade.

Table 1. GRP's production structure depending on the type of economic activity, $\%$

\begin{tabular}{|c|c|c|}
\hline \multirow{2}{*}{ Types of economic activity } & \multicolumn{2}{|c|}{ Years } \\
\cline { 2 - 3 } & $\mathbf{2 0 1 0}$ & $\mathbf{2 0 1 3}$ \\
\hline Mining & 21,6 & 22,8 \\
\hline Manufacturing & 17 & 18,3 \\
\hline Agricultural & 3,3 & 2,7 \\
\hline Construction & 5,1 & 6,3 \\
\hline Trade & 9 & 10,2 \\
\hline Olectricity, gas and water and distribution & 14 & 16,2 \\
\hline Other & 8,4 & 8,1 \\
\hline & 21,6 & 15,4 \\
\hline
\end{tabular}

The share of small and medium enterprises in the gross territorial product (GTP) of municipal areas and urban settlements of the Republic of Tatarstan in 2014, \%

Based on the analyses of the share of small and medium enterprises in the gross territorial product of municipal areas and urban settlements of the Republic of Tatarstan in 2014 we can talk about trends that not all of municipal areas are actively involved in working with business structures, which negatively affects entrepreneurial activity. The difference between the Saba municipal area - the leader in the share of small and medium-sized businesses in the gross territorial product - and the list closer Sarman municipal area is $40.7 \%$.

This difference suggests that the activities of municipal areas, aimed to stimulate and develop small business, are being handled with different effectiveness in various Tatarstan areas.

Developing property support infrastructure through all kinds of technological parks, special economic zone "Alabuga" and industrial hubs is one of the greatest examples of stimulation the small business in the Republic of Tatarstan in Table 2.

The results of operations of the abovementioned infrastructural facilities for small business support are presented

Table 2. Property support infrastructure for small business in the Republic of Tatarstan

\begin{tabular}{|l|c|c|c|c|}
\hline & Special economic zone "Alabuga" & Technopolis "Khimgrad & Kama Industrial Park "Master" & IT-park \\
\hline Number of residents & 36 & 235 & 238 & 53 \\
\hline Jobs created & 4210 & 6761 & 4460 & 2250 \\
\hline Revenue, billion rubles & 34 & 14,6 & 30 & 4,9 \\
\hline
\end{tabular}

As can be seen from Table 2, the most active platforms in terms of attracting residents are Technopolis "Khimgrad" and Kama Industrial Park "Master", which altogether have attracted more than 500 residents and created huge number of jobs.

However we shouldn't be misled by these indicators.

Many existing and potential residents note relatively high cost of using the infrastructural facilities and necessity of creating them throughout the Republic of Tatarstan.

Special economic zone "Alabuga" is a leader in terms of collecting revenue, its amount of revenue per each 
resident is approximately 1 billion rubles, which shows high level development of entrepreneurial structures on this zone.

In turn, it should be emphasized, that high economic performance indicators of entrepreneurial structures for the whole municipality area cannot be guaranteed by active role of one such platform.

Analysis of the data for the period 2005-2014 YY allows us to highlight following key trends in small business development process:

- Business gradient for small enterprises based on unformed institutional environment;

- Asymmetric development on small entrepreneurship structure;

- (increasing the share of business in service industry and outflow from the scientific services and industry)

- Enhancing of disproportion in government small business incentives at regional and local level;

- Diversion of infrastructure facilities established for small business support purposes.

\section{Conclusions}

Conducted research shows that negative trends can be leveled by using infrastructure facilities, such as financial, informational and institutional infrastructure. The financial infrastructure's role is particularly noteworthy. In a time of unstable economic situation following support measures must be taken.

- Concessional loans for small businesses via partner banks and organizations on supporting small and medium enterprises (leasing, micro-finance, factoring companies, business incubators, business centers, etc.);

- Financing of business support programs through development of local level guarantee funds, which provide surety and bail for small businesses.

Taking into account small businesses' issues we resume that further development and improvement of the entire system of governmental business support is a key factor for development of Republic Tatarstan's small business.

The proposed solutions in dealing with complex tasks in the field of Tatarstan business development allows us generate the optimal entrepreneurship structure.

In our opinion the number of business organizations and their proportional output in share of regional GDP are criterions of optimality.

\section{References}

Antonchenko N.G., Kalenskaya N.V. Developing a Methodology for Assessing the Efficacy of Managerial Decisions in Entrepreneurial Establishments (2014) Life Science Journal 11.

Grigoreva, E., Fesina, E. Economic security as a condition of institutional support of economy modernization //World Applied Sciences Journal31 (5), 2014 pp. 940-948

Kalenskaya N.V The Model of Infrastructural Support of Regional Innovative Development (2014) Mediterranean Journal of Social Sciences 18, pp. 317-323.

Kalenskaya N.V., Akhmetshin R.M., Grigoryeva L.L. The Development of State Regulation in Small Entrepreneurship Infrastructure Provision (2014) Mediterranean Journal of Social Sciences 18, pp. 27-33.

Vagizova V.I., Lurie K.M., Ivasiv I.B. Clustering of Russian banks: business models of interaction of the banking sector and the real economy/ V.I. Vagizova, K.M. Lurie, I.B. Ivasiv// Problems and Perspectives in Management. - 2014. - №1., p. 72-82

Ankudinov B., Lebedev O. V. Investment drivers of shareholder value creation in large publicly traded Russian companies // Investment Management and Financial Innovations. - 2014. - 11 (2) . - pp. 77-85.

Kalenskaya N.V, Shafigullina A.V. The Invariance as a Feature of Business Systems' Infrastructural Innovative Development (2014) Mediterranean Journal of Social Sciences 18, pp. 241-247.

Kuznetsov Y. Strategic Development of Small Businesses in Russian Regions // Asian Social Science (13), 2014, p. 231

Novikova E., Beloborodova A. An Assessment of the Efficiency of the Information System of Design-and-survey Organizations Based on the Analysis of the Information Capacity of Projects Implemented (2014) World Applied Sciences Journal 29(1), pp. 20-25.

Valeeva J.S., Sharafutdinova N.S., Kulkova V.Y., Quality management system's role in operation of retail trade networks (2014) Life Science Journal 11(5), pp. 555-558.

Wyrwich, M. Regional Entrepreneurial Heritage in a Socialist and a Postsocialist Economy // Economic Geography 88 (4), 2012. pp. 423445

Zheleva S.E., Saktoev V.E., Tsyreneva E.D., Industrial aspects of socio-economic systems' sustainable development (2005) VSGTU press, p.156.

Klaas J., Vagizova V. Formation of sustainable development strategy of credit organizations based on Balanced Scorecard // Investment Management and Financial Innovations. - 2014. - № 1. c. 87-96. 